\title{
EEN KOREAANSE SCHILDERTRADITIE WORDT BEVESTIGD DOOR EEN RECENTE SCHENKING
}

\begin{abstract}
De schenking van een belangwekkende Koreaanse schildering aan het Rijksmuseum voor Volkenkunde is een mooie aanleiding om eens serieuzer te kijken naar de ontwikkelingen op het gebied van de traditionele en neotraditionele schilderkunst in dat land. De schildering van de hand van Seokhyang Jeong Eui-ju is een uitstekend voorbeeld van de vitaliteit van een traditie die even dreigde verloren te gaan.
\end{abstract}

\section{De Koreaanse schilderkunst binnen de Oostaziatische tradities}

Met de openstelling van China, Japan en Korea in het midden en de tweede helft van de $19^{\mathrm{e}}$ eeuw veranderde er veel in de praktijk van de schilderkunst van die landen. Net als China en Japan was Korea tot die ingrijpende veranderingen een rigide samenleving die autoritair vanuit het centrum werd bestuurd. Die rigiditeit was ideologisch zo mogelijk nog sterker in Korea dan in Japan of China, mede omdat het land kleiner en homogener was. De plaats en functie van de schilderkunst was dan ook sterk ideologisch bepaald. Ook in het Korea van de Joseon-periode $(1392-1910)^{1}$ werd een duidelijk onderscheid gemaakt tussen enerzijds schilderkunst en kalligrafie voortgekomen uit individuele creativiteit en anderzijds werk van aan de academie opgeleide schilders die in opdracht werkten. Zij waren ambachtslieden wier werk daarnaast ook een esthetische waarde kon hebben. Volgens de opvattingen van het confucianisme, de staatsideologie, moest een schildering vooral deugden als kinderlijke piëteit, trouw aan de vorst en geletterdheid uitdrukken. De specifieke invloed van het neo-confucianisme op de schilderkunst is de nadruk op eenvoud en de afkeer van puur decoratieve elementen. Een ander ideaal is dat esthetiek in principe immaterieel is, en dus niet verhandelbaar. Dergelijke opvattingen hebben ervoor gezorgd dat ook in tijden van betrekkelijke economische voorspoed de welvaart de productie nauwelijks stimuleerde. Autonome kunst vervaardigd door de elite van literaten (de stand van de yangban) werd niet geproduceerd voor geldelijk gewin. Hierbij dient vermeld te worden dat ook enkele vrouwen zich als kundige literatenschilders hebben geprofileerd.

In de $18^{\mathrm{e}}$ en $19^{\mathrm{e}}$ eeuw bestond tevens een bloeiende en levendige traditie van volksschilderkunst. De makers van deze schilderingen hadden geen formele opleiding genoten en waren derhalve in principe geheel vrij in de keuze van technieken of materialen. Toch zijn er in deze tak van kunst ook vele symbolen te vinden die ontleend zijn aan de elite van de literaten. De markt voor dergelijke, vaak naïeve, schilderkunst was vrij groot, omdat daarmee zowel in decoratieve als religieuze behoeften werd voorzien. De thematiek van deze schilderingen was navenant gevarieerd, van scènes uit het dagelijks leven tot stillevens, maar ook mythische voorstellingen of afbeeldingen van goden. In tegenstelling tot in Japan bijvoorbeeld bestond geen massaconsumptie van access 
kunstig vervaardigd drukwerk dat vooral om zijn decoratieve kwaliteiten werd verkocht. Wel was er een grote markt voor (zwart-wit) geïllustreerde boeken, meestal confucianistisch en moralistisch van aard. Pas in de laatste veertig jaar is de waardering voor deze vaak humoristische en speelse vorm van schilderkunst te vergelijken met die voor de formele schilderkunst. Een goed voorbeeld van zulke volksschilderingen (minhwa) is een kamerscherm dat zich in het Rijksmuseum voor Volkenkunde in Leiden bevindt (afb. 1). Schilderkunst was analoog aan de standenmaatschappij gesegregeerd. Slechts weinig ambtelijke beroepsschilders werden zodanig gewaardeerd als kunstenaars dat zij hetzelfde prestige genoten als de beste literatenschilders. De late Joseon-periode kan worden gekenschetst als de tijd waarin de amateurschilderkunst van de literaten dominant was, maar het was ook de tijd waarin enkele academische schilders een bijzondere reputatie konden verwerven. Aan het eind van deze periode, na de openstelling van het land in 1876 , komen eerst drie decennia van consolidatie waarin nationale eigenschappen worden benadrukt, maar waarin ook de sociale positie en functie van de literatenschilderkunst in de verdrukking komen.

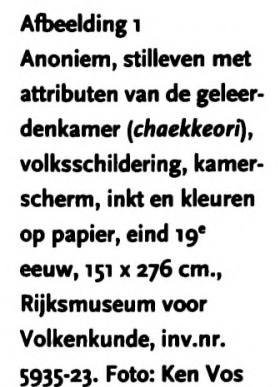

5935-23. Foto: Ken Vos

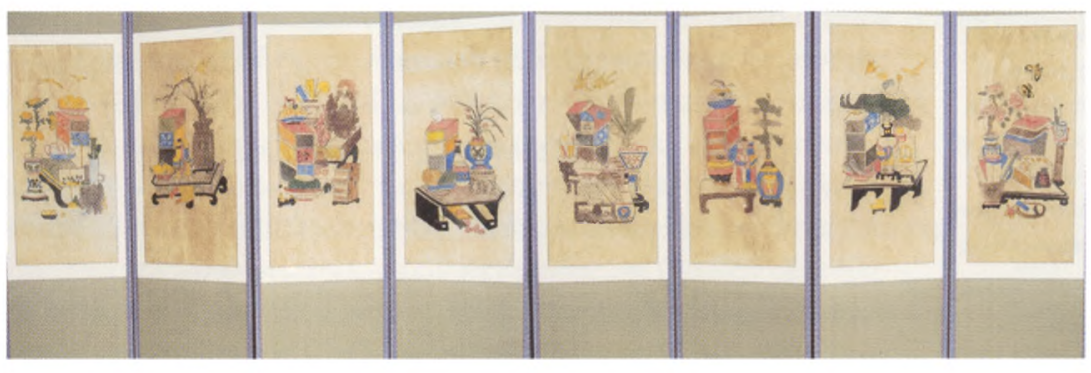

Hoogtepunten in de schilderkunst vanaf de

\section{$13^{\mathrm{e}}$ tot en met de $18^{\mathrm{e}}$ eeuw}

In grote lijnen loopt de geschiedenis van de schilderkunst op het schiereiland parallel aan de politieke geschiedenis, niet verwonderlijk als men bedenkt dat de productie altijd nauw samenhangt met het welvaren van de afnemers van de schilderingen. Van de vroegste Koreaanse schilderkunst tot de Goryeo (935-1392) is vrijwel niets overgebleven, als men media als muurschilderingen en drukwerk even buiten beschouwing laat. Het is tekenend dat juist van de eerste tijd dat er een iets groter aantal schilderingen bekend is, meerdere tientallen, juist tamelijk veel zich in het buitenland bevinden. Dat zijn boeddhistische schilderingen uit voornamelijk de $13^{\mathrm{e}}$ en $14^{\mathrm{e}}$ eeuw, waarvan zich één ook in het Rijksmuseum zou bevinden. 'Zou', want de identificatie van deze, meestal anonieme schilderingen is vaak problematisch. Het feit dat zoveel van deze boeddhistische werken in het buitenland te vinden zijn, heeft zowel met de Koreaanse geschiedenis als met de hoge waardering van deze schilderingen te maken. Immers, in de $13^{e}$ eeuw werden deze schilderingen ook in China en Japan zeer hoog gewaardeerd om hun decoratieve kwaliteit. Helaas zijn tijdens de plunderingen van de Japanners en de Mantsjoes in de $16^{\mathrm{e}}$ en $17^{\mathrm{e}}$ eeuw vele kunstschatten in Koreaanse tempels verloren gegaan. Was de boeddhistische kunst in Goryeo dominant, vanaf het begin van de Joseon zijn wereldlijke, lees confucianistische, opvattingen bepalend voor de schilderkunst. De academie voor schilderkunst wordt onder een andere benaming, Dohwaso, voortgezet, en voorbeelden uit de Ming-periodezallenccess 


\section{Afbeelding 2}

Kim Myeong-guk (160063), Bodhidharma, inkt op papier, 82,8 857,5 cm., National Museum of Korea, Seoul. Uit: Koreana. Korean Cultural Heritage, Vol. 1: Fine Arts, Seoul, 1994

\section{Afbeelding 4}

(linksonder)

Kim Hong-do (1745-ca. 1806), Gezicht op de Pyohun tempel in het Geungang gebergte, albumblad, inkt en kleuren op zijde, 1796, $30,4 \times 43,7$ cm., particulier bezit. Uit: Choe, Wan-su e.a., The Art of Kim Hong-do. The special exhibition catalogue commemorating his $25^{\circ \text { th }}$ anniversary,

Seoul, 1995

\section{Afbeelding 5} (rechtsonder) Kim Hong-do (1745-ca. 1806), De bouw van een huis, rond 1800 , albumblad, inkt en kleuren op papier, $27 \times 22,7 \mathrm{~cm}$., National Museum of Korea, Seoul. Uit: Choe, Wan-su et al. Op.cit.
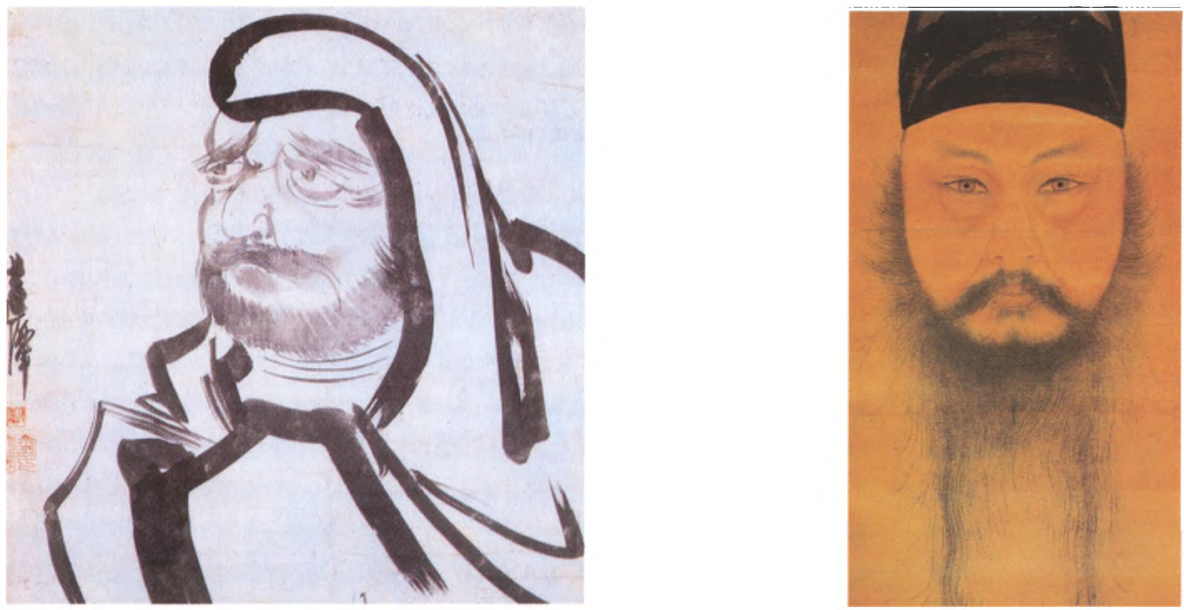

tot in de $18^{\mathrm{e}}$ eeuw bepalend zijn voor zowel de academische als de literatenschilderkunst. Naar Chinees voorbeeld ontwikkelt zich ook de portretkunst waarin behalve realisme, individuele karaktereigenschappen een steeds voornamere rol gaan spelen. Een bekend voorbeeld is het zelfportret van Yun Du-seo (artiestennamen Gongjae en Jong'ae, 1668-1715) (afb. 3). Een merkwaardigheid is dat Yun een schilder van de literatenstand was, terwijl portretten meestal werden gemaakt door beroepsschilders. Yun was ook een van de eerste schilders die zich toelegde op het afbeelden van activiteiten in het dagelijks leven. Deze aandacht voor karaktereigenschappen van individuen, voorgespiegeld of reëel, zien we ook in de staatsie- en voorouderportretten van latere beroespsschilders. De aandacht voor de menselijke figuur als dynamisch element in zijn omgeving is echter altijd onderbelicht gebleven in de Koreaanse kunst. De mens werd dan bij voorkeur schetsmatig in enkele basishoudingen afgebeeld. De latere genreschilderingen van Kim Hong-do en Sin Yun-bok (zie hier onder) vormen met hun aandacht voor het emotionele detail daarop een historische uitzondering.

Vanaf eind $17^{\mathrm{e}}$ eeuw neemt de invloed van de zogeheten zuidelijke school toe, waarin het monumentale, geïdealiseerde landschap plaats maakt voor composities waarin de mens een belangrijkere rol speelt. Haast synchroon
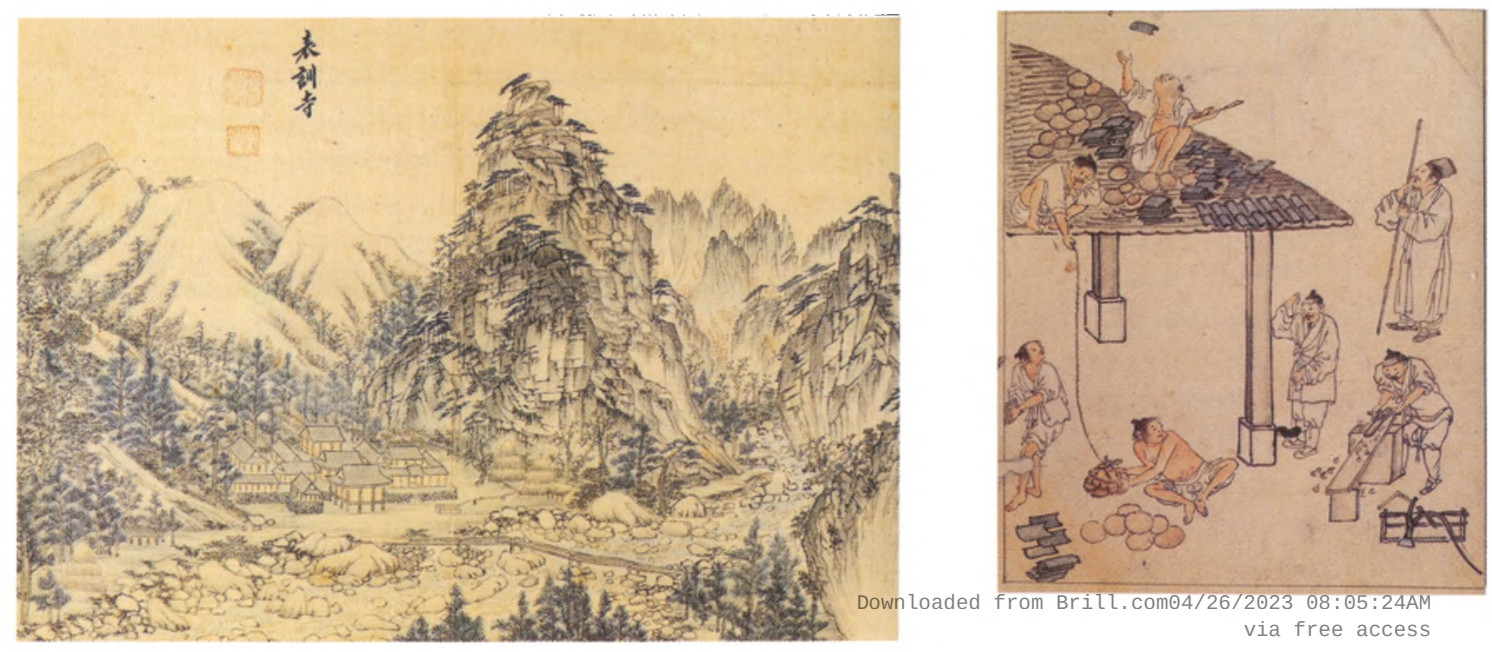

via free access 
Afbeelding 3 (links) Yun Du-seo (1668-1715), zelfportret, inkt en waterverf op papier, $38,5 \times 20,5 \mathrm{~cm}$., particulier bezit. Uit: Koreana. Op.cit.

\section{Afbeelding 6} (linksonder) Jeong seon (1676-1759), Geumgang jeondo (Volledig gezicht op de Geungang-bergen), inkt en waterverf op papier, 1734, 130,7 x 94.1 cm., Hoam Art Museum, Yongin. Uit: Koreana. Op.cit.

\section{Afbeelding 7}

(rechtsonder)

Gang Se-hwang (171391), Baeksokdam (een vijver in Songdo), albumblad, inkt en kleuren op papier, $32,8 \times 53,4 \mathrm{~cm}$., National Museum of Korea, Seoul. Uit: Koreana. Op.cit. daaraan, vanaf rond 1700 , onder leiding van eigenzinnige en kundige schilders als Jeong Seon (artiestennaam Gyeomjae, 1676-1759) wordt het concept van het echte landschap (jin'gyeong sansu) steeds belangrijker. De schilders van jin'gyeong sansu houden zich bezig met het afbeelden van het daadwerkelijk ervaren landschap, en daarmee ook vooral het Koreaanse landschap. In de $18^{\mathrm{e}}$ en het begin van de $19^{\mathrm{e}}$ eeuw zien we een wederopleving van de schilderkunst, waarin ook beroepsschilders een belangrijke rol spelen. De bekendste onder hen is Kim Hong-do (artiestennaam Danwon, 1745ca.1806) die in verschillende genres, zoals de documentaire schilderkunst, genreschilderkunst en de literatenschilderkunst, uitmuntte (afb. 4 en 5). Deze laatste categorie heeft als thematiek landschappen, vogel- en bloemcomposities, stillevens, de vier 'heren' of elegante planten (bamboe, chrysant, orchidee en pruimebloesem). De dynamiek en humor van Kim Hong-do - in Korea worden schilders meestal aangeduid met hun burgelijke naam en niet met hun kunstenaarspseudoniem - vindt men ook terug bij zijn collega en tijdgenoot Sin Yun-bok (artiestennaam Hyewon, 1758-?). Ook zien we dat in de $18^{\mathrm{e}}$ eeuw via China enige Westerse invloed zich kenbaar maakt in het werk van kunstenaars, zoals de invloedrijke literatenschilder en kunstcriticus Gang Se-hwang (Pyoam en Pyo'ong, 1713-91), met toenemende dieptewerking door middel van kleurverloop en perspectief.

\section{Stagnatie en restauratie in de $19^{\mathrm{e}}$ eeuw}

In de $19^{\mathrm{e}}$ eeuw maken de verworvenheden van de laatste eeuw langzamerhand plaats voor een nieuw conservatisme waarin de zuidelijke school weer de boventoon voert. De belangrijkste voortrekker van deze neo-conservatieve tendens is de literaat Kim Jeong-heui (Chusa, 1786-1856) die echter wel een vernieuwer is als kalligraaf. Verfijning en vereenvoudiging van de bekende thema's kenschetsen Chusa en zijn volgelingen. In dit klimaat kunnen zich wederom schilders als Kim Su-cheol (Buksan, actief tweede helft $19^{\mathrm{e}}$ eeuw) en Hong Se-seop (Seokchang, 1832-84) ontwikkelen die grotere contrasten in kleur en compositie ontlenen aan buitenlandse inspiratiebronnen. De modernisering heeft ook gevolgen voor de positie van de schilderkunst in de samenleving. De schilderkunst voor het hof, nog steeds uitgeoefend door de aan de Dohwaso opgeleide schilders, krijgt steeds decoratievere trekken, hetgeen tot
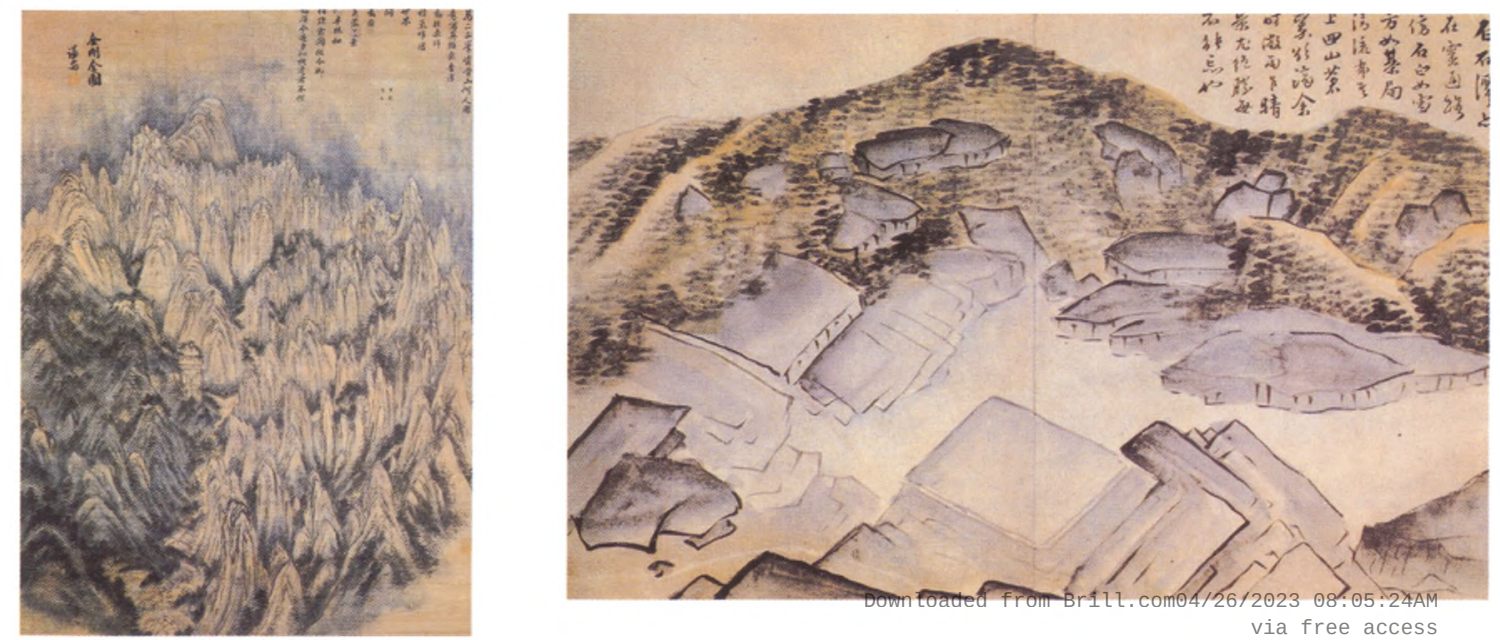
uitdrukking komt in volledig uitgevulde composities met harde, nieuwe, vaak synthetische kleuren. Een mooi geromantiseerd beeld van de plaats van de getalenteerde, traditionele schilder in deze tijd van stagnatie geeft de film Chihwaseon van de bekende regisseur Im Kwon-Teak uit 2001. Deze film maakt gebruik van de vele anekdotes rond de onbehouwen schilder Jang Seung-eop (Owon, 1843-97) om de sociale inertie van deze periode te beschrijven.

De schilderkunst in het algemeen krijgt langzamerhand een autonome plaats in de samenleving, terwijl verschillende praktijken in het onderwijs en de beroepsuitoefening, Westers en autochtoon, naast elkaar bestaan. Nu volgt een moeilijke periode voor de traditionele schilderkunst, nu Joseonhwa, later in het zuiden Han'gukhwa, genaamd, waarin vernieuwing vooral uit het Westen (uitgevulde achtergrond, kleurgebruik) of Japan (minder diepte, heldere vlakverdeling met scherpe contouren) wordt geïntroduceerd. Dit gaat ten dele ten koste van stijlelementen die de schilderingen een direct herkenbaar Koreaans karakter geven, zoals het gevarieerde penseelgebruik in het aangeven van contouren en bijvoorbeeld vegetatie.

\section{Gisan, genreschilder in buitenlandse collecties}

Het werk van de commerciële schilder Gisan (Kim Jun-geun, tweede helft $19^{\mathrm{e}}$ eeuw) valt buiten de gebruikelijke kaders van de Koreaanse schilderkunst (afb. 8-9). Veel weten we niet van Gisan, zijn burgerlijke naam kennen we slechts van één signatuur op een werk dat zich in Korea bevindt en van één signatuur op een werk in Leiden. Onze kennis is beperkt tot wat we weten omtrent de verwerving van de werken in de havensteden Busan, Jemulpo (het huidige Incheon) en Wonsan. Toch moet zijn werk in dit verband genoemd worden, omdat zijn schilderingen in Europa en Amerika van grote invloed zijn geweest op onze visuele kennis van de Koreaanse cultuur. Er zijn meer dan duizend werken geïdentificeerd in de verschillende collecties in Duitsland, Oostenrijk, Denemarken, Frankrijk, Groot-Britannië, Nederland, Rusland, Canada en de Verenigde Staten. Stilistisch doen de genreschilderingen het meest denken aan boekillustraties en ze zijn inderdaad als zodanig gebruikt in het eerste engelstalige boek over Koreaanse cultuur, Korean Games van Stewart Culin, dat voor het eerst in 1895 werd gepubliceerd. Het werk van Gisan vertoont qua compositie zekere overeenkomsten met Kim Hong-do, maar hij lijkt ook beïnvloed te zijn door de populaire Chinese exportschilderingen uit Ningbo. Gezien de variatie in detaillering en afwerking, zoals in de vormen van de gezichten lijkt het erop dat er sprake was van een atelier, maar er zou ook een ontwikkeling in het kunstenaarschap kunnen zijn, aangezien de stukken in Toronto van een iets betere expressiviteit getuigen. Deze zijn namelijk iets later door een Canadese zendeling aangekocht dan de serie in Leiden.

De drieëntwintig stukken in het Rijksmuseum voor Volkenkunde zijn verworven door Jan Rhein die tussen 1887 en 1892 als vertaler en secretaris werkzaam was op de Nederlandse vertegenwoordiging te Peking en in die hoedanigheid ook naar Korea reisde. De verzameling werd door hem in 1888 aan het museum geschonken. Het kleine formaat van de werken wijst erop dat ze kennelijk bedoeld waren als albumbladen. Alle werken, op één na, zijn voorzien van het zegel Gisan. Het overgebleven stuk draagt een zegel met zijn eigenlijke naam, Kim Jun-geun. Toevalligerwijs zijn dit jaar twee tentoonstellingen aan deze schilder gewijd. In de tentoonstelling 'Korea Around 1900 : 


\section{Afteelding 8 (links)} Gisan (Kim Jun-geun), Bezoek aan een bevriende gevangene, schildering in inkt en waterverf op papier, zegel: Gisan, ca. 1880, $19.7 \times 18.6$ cm., Rijksmuseum voor Volkenkunde, inv.nr. 679-25. Foto: Monique Koek De gevangenis diende ter opsluiting vóbr de eventuele veroordeling.

Afbeelding 9 (rechts) Gisan, Maskerdans, schildering in inkt op papier, zegel: Gisan, ca. $1880,21.0 \times 17.0 \mathrm{~cm}$., Rijksmuseum voor Volkenkunde, inv.nr. 679-28, Foto: Monique Koek Maskerdansen werden gebruikt om sociale misstanden aan de kaak te stellen.
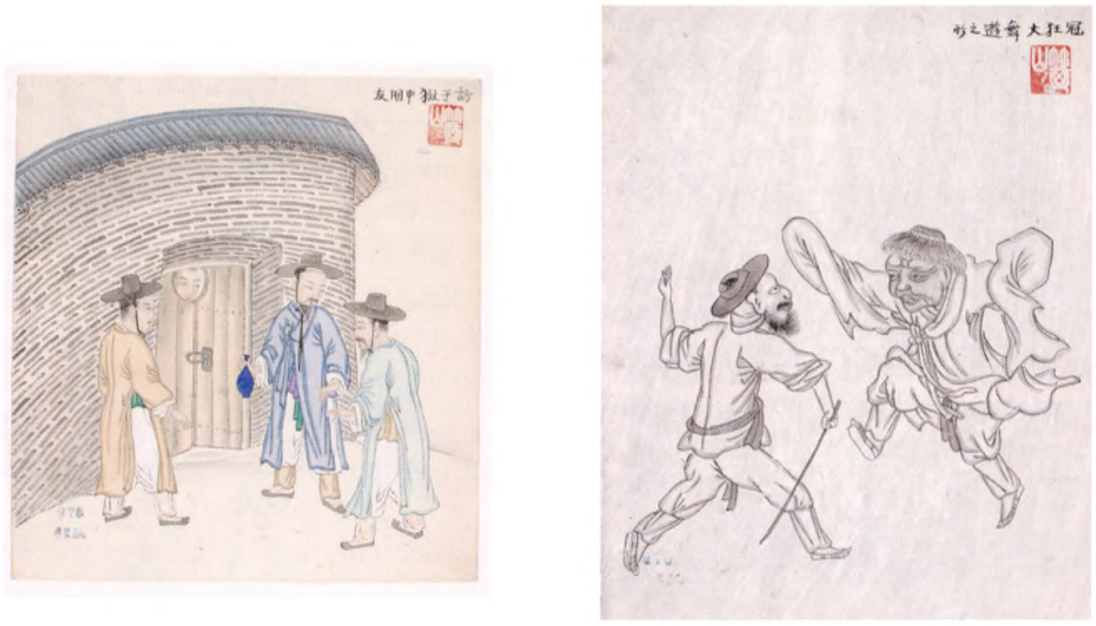

The Paintings of Gisan' in het Royal Ontario Museum te Toronto zijn naast de drieëndertig uit de collectie van het ROM ook alle werken uit Leiden te zien. Ter gelegenheid van deze tentoonstelling is ook een nuttige catalogus van de hand van Christina Han verschenen. ${ }^{2}$ In het Nationaal Museum te Kopenhagen zijn in de tentoonstelling 'Korea på Bestilling - Kisans malerier fra 1890'erne' veertig van de 98 stukken uit het depot te zien. Er wordt nu gekeken of volgend jaar een dergelijke tentoonstelling in Leiden gehouden kan worden, eventueel met toevoeging van multimediale animatieprogramma's die in opdracht van de Koreaanse overheid ontwikkeld worden voor een Gisan-website.

\section{Ontwikkelingen in de eerste helft van de $20^{\mathrm{e}}$ eeuw}

Als we de ontwikkelingen in de Westerse schilderkunst buiten beschouwing laten, zien we in Korea vooral waardering voor kunstenaars die Koreaanse elementen laten domineren zonder vernieuwingen uit de weg te gaan. Schilderkunst uit deze tijd krijgt deels achteraf een nieuwe politieke betekenis, omdat tijdens de Japanse annexatie (1910-45) natuurlijk invloeden uit dat land bijzonder sterk waren. Er zijn echter ook schilders als Yi Yong-u (Mukno, 1904-52), of Yi Sang-beom (Cheongjeon, 1897-1972) of Byeon Gwan-sik (Sojeong, 1899-1976) die juist deze invloeden incorporeren binnen de traditie van de inktschilderkunst van de literaten (afb. 10). Deze grote drie van de neo-traditionele schilderkunst zorgen er ook voor dat er een institutioneel

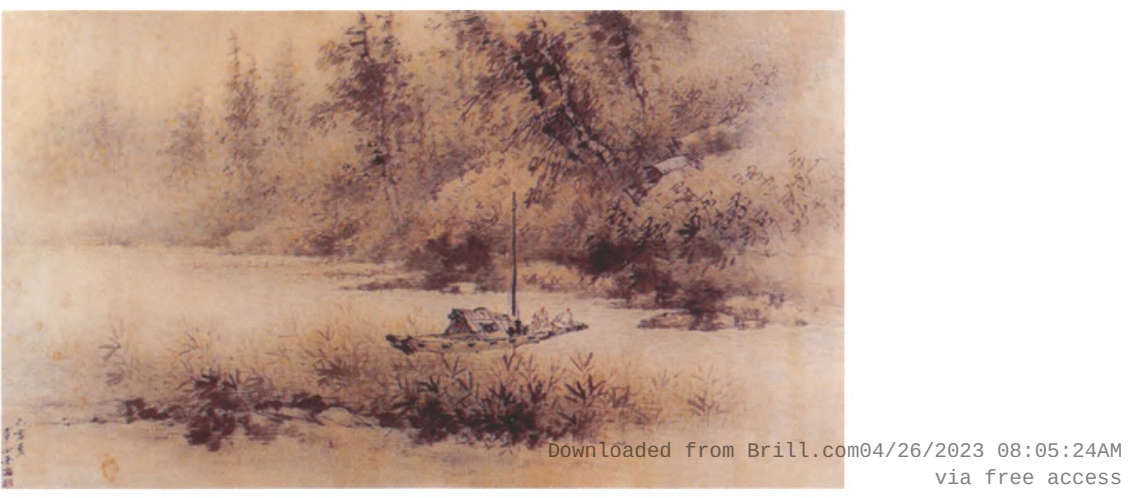



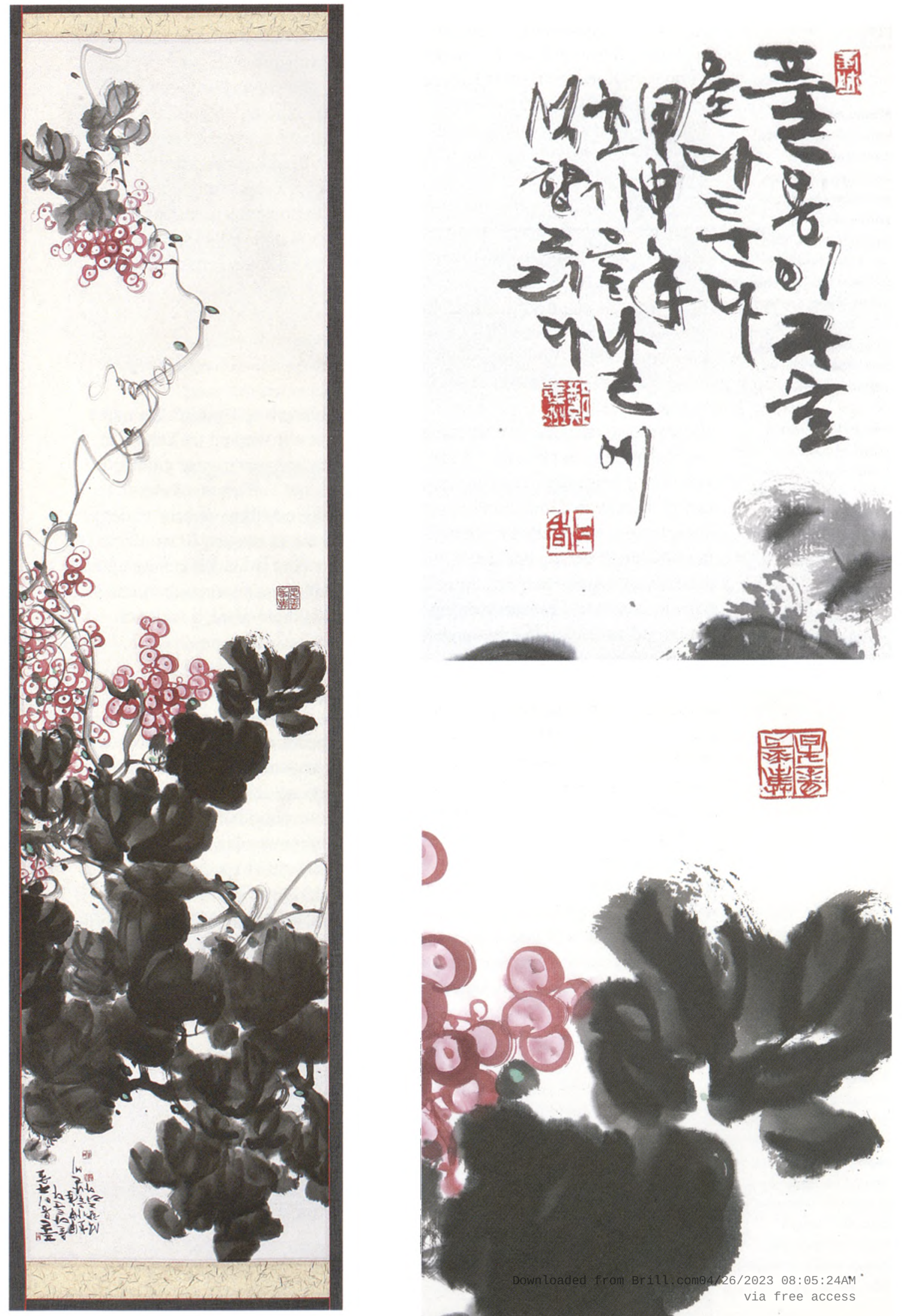

)
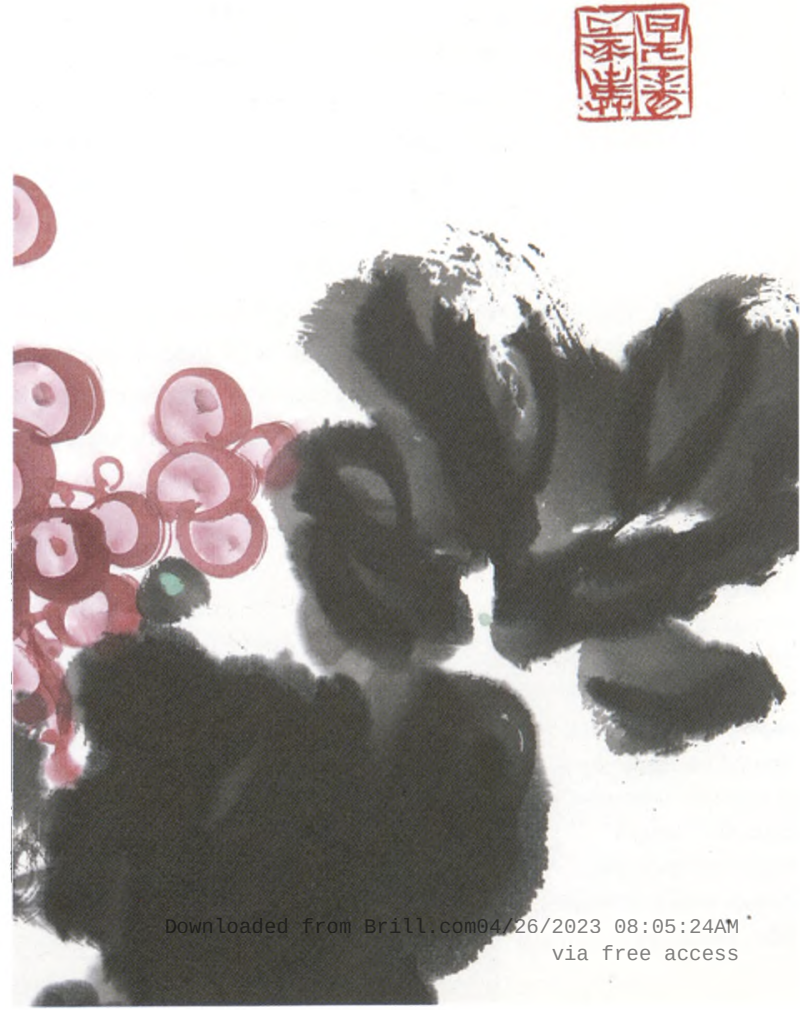
kader komt voor dergelijk werk in de vorm van een kunstenaarsorganisatie die ook jaarlijkse nationale competities organiseert. Opvallend is bijvoorbeeld dat de zen (Kor.: seon) in de Koreaanse schilderkunst nauwelijks een eigen

Afbeelding 1 (geheel links) Jeong Eui-ju, Druivenranken, inkt op papier, gesigneerd: Seokhyang geurida, $137,2 \times 34,7 \mathrm{~cm}$., Rijksmuseum voor Volkenkunde, inv.nr. 6046-1. Foto: Ken Vos

Afbeelding 12 en $12 a$ Details van Druivenranken, zegels en signatuur. Foto: Andrew Thompson plaats heeft, terwijl juist de zen-secten het sterkst vertegenwoordigd zijn in de lokale boeddhistische praktijken. Het is erg waarschijnlijk dat de Japanse schilderkunst de terugkeer van zen-thematiek en -opvattingen in de Koreaanse schilderkunst heeft gestimuleerd. Na de Tweede Wereldoorlog, wanneer het land in twee zones is verdeeld, worden steeds meer Westerse invloeden in de traditionele inktschilderkunst opgenomen, maar van een verdere verwestersing in de technieken, basisvormen en thematiek is nauwelijks sprake.

\section{Een schenking van de schilder Jeong Eui-ju}

Buiten Korea zelf zijn helaas geen representatieve verzamelingen van Koreaanse schilderkunst te vinden, zelfs als men zich beperkt tot een betrekkelijk korte historische periode, zoals bijvoorbeeld de late Joseon (1750-1910). Voor Nederland dat na de openstelling in 1876 geen belangstelling toonde voor het land, geldt dat zelfs in versterkte mate. Gezien het belang en de kwaliteit van de schilderkunst is dat spijtig, te meer daar de kunst van de buurlanden van Korea een stuk beter is vertegenwoordigd in Nederland. Gezien de marktsituatie (hoge prijzen, beperkte verkrijgbaarheid) en het gebrek aan kennis is het daarom des te verheugender dat een bekende, nog vrij jonge schilder als Jeong Eui-ju het van belang achtte om een van zijn beste werken aan een Nederlands museum te schenken (afb. 11). Het werk is niet alleen representatief voor het oeuvre van Jeong (artiestennaam Seokhyang), maar ook voor dat deel van de hedendaagse Zuidkoreaanse schilderkunst die nog altijd de literatenschilderkunst (muninhwa) wordt genoemd. In de praktijk is deze term vaak inwisselbaar met het begrip hangukhwa, aangezien juist de literatenschilderkunst als het meest representatief voor de Koreaanse traditie wordt beschouwd.

Uiteraard is er in Korea geen sprake meer van yangbang of een literatenelite, maar bepaalde levensopvattingen en de daarbij behorende neo-Confucianistische principes zijn in het hedendaagse Zuid-Korea nog opvallend sterk aanwezig. Hoewel kleurgebruik, lijnvoering en vlakverdeling steeds vrijer worden, blijven de basisthema's dezelfde: landschappen, bloemen en vogels, stillevens, de vier elegante planten en uiteraard kalligrafie. Expressie staat nog steeds gelijk aan intentie, en decoratieve eigenschappen blijven ondergeschikt aan expressiviteit. Het lijkt erop dat ondanks een ware explosie aan hedendaagse kunstvormen, ook deze zogeheten nationale schilderkunst in kwantiteit expandeert. Het spreekt voor zich dat elementen van de hangukhwa daarbij ook een inspiratiebron voor de hedendaagse beeldende kunst vormen.

Jeong werd in 1964 geboren te Gunsan in de provincie Jeollabuk-do. Zijn familie heeft al meerdere generaties literatenschilders voortgebracht, maar hij volgde wel een formele opleiding in dit vak. Tegenwoordig heeft hij zijn atelier in Jeonju, de hoofdstad en het culturele centrum van dezelfde provincie. De betreffende schildering hing in de kleine hal vóór het eigenlijke atelier waar enkele van zijn beste werken tentoongesteld zijn. Blijkens een overzicht in een kleine catalogus uit 2004 heeft hij tenminste negen onderscheidingen voor zijn werk ontvangen, waarvan als belangrijkste de eerste prijs van de Daehanminguk Misul Daejeon (Grote Koreaanse Kunsttentoonstelling, een national overzicht van de belangrijkste geselecteerde kunstwerken van dataccess 

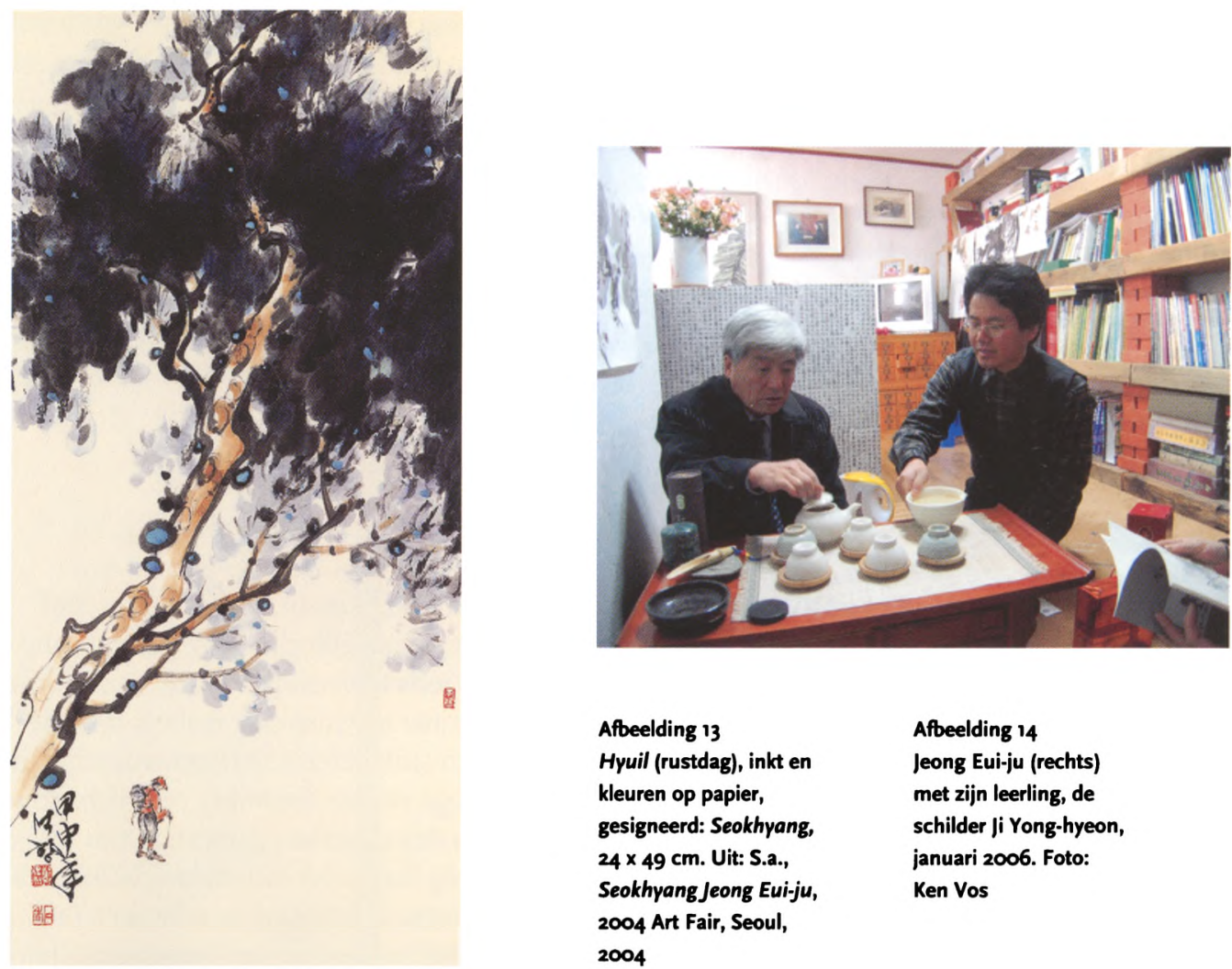

Afbeelding 14 Jeong Eui-ju (rechts) met zijn leerling, de schilder fi Yong-hyeon, januari 2006. Foto: Ken Vos

jaar) in 2003 genoemd kan worden. ${ }^{3}$ Deze schildering is in het jaar daarop vervaardigd.

De inktschildering op papier stelt hangende druivenranken voor, vanwege de in elkaar overlopende bogen van de takken een populair thema in de literatenschilderkunst vanaf de $15^{\mathrm{e}}$ eeuw. De stijl van schilderen sluit direct aan op de $19^{\mathrm{e}}$-eeuwse namhwa-traditie aan. Sterke punten van het werk zijn de vloeiende, zekere penseelvoering bij de voorstelling van de druiven aan de ranken en de krachtige nuancering van het gebladerte. Subtiele schakeringen in de dichtheid van het inktgebruik geven een grote expressiviteit aan deze conservatieve voorstelling. Dit zijn ook juist de eigenschappen die het werk van Seokhyang typeren. Dergelijk, grotendeels traditioneel schilderwerk wordt tegenwoordig in Zuid-Korea nog op grote schaal beoefend en tentoongesteld. Jeonju, waar de schilder woont en werkt, is het belangrijkste centrum van deze literatenschilderkunst. Als cultureel fenomeen zijn deze literatenschilderingen (muninhwa) een materiële uiting van de continuïteit van het sterk Confucianistische karakter van de Koreaanse samenleving. Opvallend is dat de signatuur afgezien van de cyclische jaaraanduiding in hangeul, het Koreaanse alfabet, is. Chinese karakters worden in deze stijl overigens nog dikwijls gebruikt. De tekst rechtsboven luidt: P'uryong-i guseur-eul dat'unda. Gapsinnyeon chogaeullar-e Seokhyang geurida (Grasdraken vechten om juwelen. Op de eerste herfstdag van het jaar van de aap schildert Seokhyang). Het zal duidelijk zijn dat met grasdraken de ranken worden bedoeld en dat met juwelen de vruchten aangeduid worden. De twee zegels onder de signatuur zijn respectievelijk Jeong Eui-ju in Chinese karakters en Seokhyang in hangeul. 

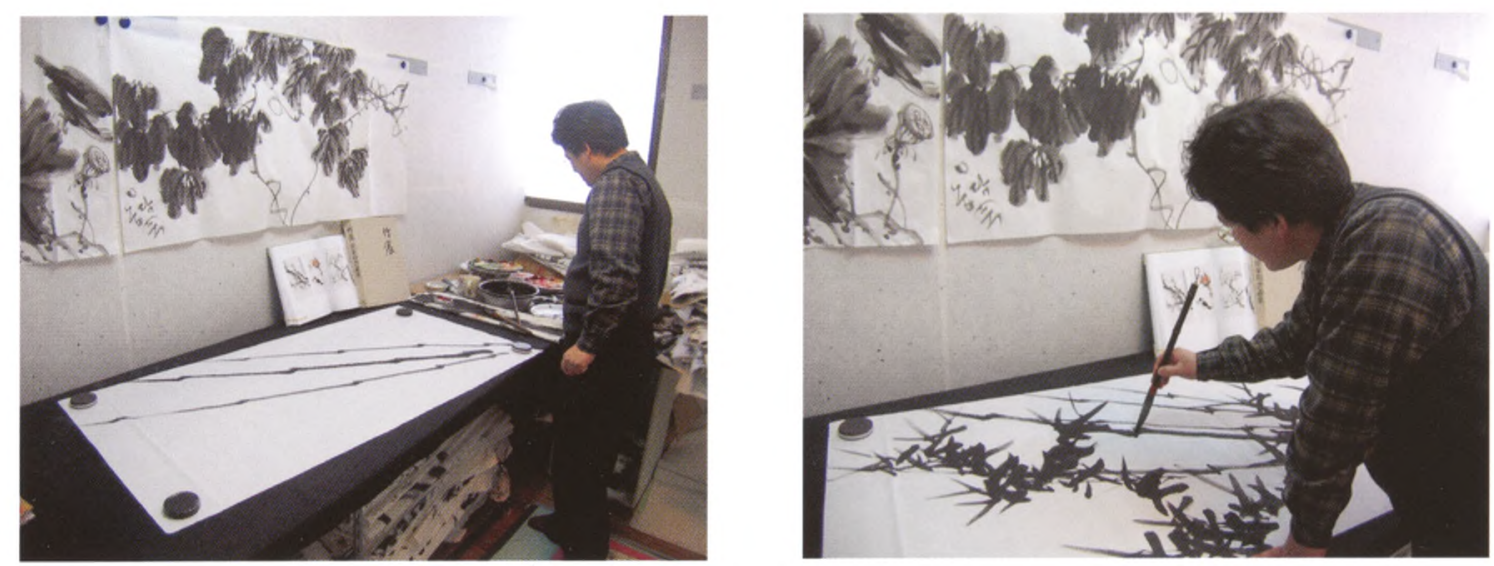

Afbeelding 15 (links) Jeong Eui-ju werkend in zijn atelier, januari 2006. Foto: Ken Vos

Afbeelding 16 leong Eui-ju werkend in zijn atelier, januari 2006. Foto: Ken Vos

\section{Noten}

1. Voor het Koreaans wordt in dit artikel het in $\mathbf{2 0 0 0}$ geïntroduceerde transliteratiesysteem van het Ministerie van Cultuur en Toerisme van de Republiek Korea gehanteerd. Dat houdt in dat in vergelijking met het tot voor kort in academische kringen geprefereerde systeem van McCune-Reischauer alle diacritische tekens vervallen. Zo worden ǒ en ŭ nu respecievelijk als eo en eu geschreven. Niet-geaspireerde medeklinkers worden nu gespeld als stemhebbende: $g$ in plaats van $k, j$ in plaats van ch, enzovoorts. Geaspireerde medeklinkers worden als stemloze medeklinkers geschreven: $t$ ' wordt zo $t$. Dit heeft onder meer tot gevolg dat Koryŏ nu als Goryeo wordt geschreven en Chosŏn als Joseon. In de praktijk zijn er alweer allerlei uitzonderingen gesignaleerd. Zo wordt de familienaam Kim zeer zelden met een ' $g$ ' geschreven.

2. C.H.Y. Han, Korea Around 1900: The Paintings of Gisan, Royal Ontario Museum, Toronto, 2006.

3. Seokhyang Jeong Eui-ju, 2004 Art Fair, Seoul, 2004 